\title{
An Analysis of Students Problem That Affects Their Studies Using Fuzzy Max-Min Composition Technique
}

\author{
${ }^{1}$ M.GeethaLakshmi, ${ }^{2}$ N.Jose parvin Praveena, ${ }^{3}$ A.RajKumar \\ ${ }^{1}$ KCG College of Technology, ${ }^{2}$ KCG College of Technology, ${ }^{3}$ Hindustan University.
}

\begin{abstract}
An Introduction of a new technique named fuzzy max-min composition to study Sanchez's approach for the analysis of Students Problems that affects their studies with the help of Intuitionistic fuzzy sets. Through a survey we discuss about the problems of Students and with that problem and with the help of Intuitionistic fuzzy relations along with max-min composition technique we analyse the problems Students that affects their Studies.
\end{abstract}

Key words: - Fuzzy set, Intuitionistic fuzzy set (IFS), Intuitionistic fuzzy relations (IFR), max-min operation.

\section{Introduction}

Education is one of the most important aspects in society and hence should be taken with optimal seriousness. Students play a major role and Many students have an absolute desire to study in various colleges. In the process of learning, there are many different problems that face students either within the Campus or outside the campus. These problems are very severe that most of the college students are unable to adequately and competently complete their studies.

Some students are having great problems in paying their fees which have hiked up at a very high rate. This has made many students fail to complete their undergraduate courses as they cannot pay the whole amount of money required. It has been indicated that, the prices of text books which are very essential to the students are very high hence causing most of the students in college to fail to utilize them. Financial problems among college students typically lead to their drop in studies as they are in most cases stressed up. Some students will be having problems in their studies and hence problems will increase since their credits will lower

Despite the fact that most of the college students faced with problems of homesickness, a number of students at one time or the other get homesick. Some students study more than three hours before getting back to their homes and hence chances of getting homesick are noticeable.

Some of them facing Drowsiness, some face Memory Loss, Some facing Family Problems, Some Facing Adolescent Problems etc., all these problems have indicated that, students are at great risk of failing to complete their courses. Using max-min technique we are going to analyze the common problems of students that affect their studies with the help of Intuitionistic fuzzy relations.

In real world, we frequently deal with vague or imprecise information.Information available is sometimes vague, sometimes inexact or sometimes insufficient. Out of several higher order fuzzy sets, intuitionistic fuzzy sets (IFS) [1,2] have been found to be highly useful to deal with vagueness. There are situations where due to insufficiency in the information available, the evaluation of membership values is not possible up to our satisfaction. Due to the some reason, evaluation of non-membership values is not also always possible and consequently there remains a part in deterministic on which hesitation survives. Certainly fuzzy sets theory is not appropriate to deal with such problem, rather IFS theory is more suitable. Out of several generalizations of fuzzy set theory for various objectives, the notion introduced by Atanassov [1] in defining intuitionistic fuzzy sets is interesting and useful. Fuzzy sets are intuitionistic fuzzy sets but the converse is not necessarily true [1]. In fact there are situations where IFS theory is more appropriate to deal with [8]. Besides, it has been cultured in [9] that vague sets [11] are nothing but IFS.

In the present paper we use Sanchez's method for analysis of students problem using the notion of IFS theory.

\section{Preliminaries}

We give here some basic definitions, which are used in our next section.

\section{Definition}

Let a set $\mathrm{E}$ be fixed. An Intuitionistic fuzzy sets or IFS A in $\mathrm{E}$ is an object having the form $\mathrm{A}=\left\{\left\langle x, \mu_{A}(x), \gamma_{A}(x)\right\rangle / \mathrm{x} \in \mathrm{E}\right\}$ where the functions

$\mu_{A}: \mathrm{E} \rightarrow[0,1]$ and $\gamma_{A}: \mathrm{E} \rightarrow[0,1]$ define the degree of membership and degree of non-membership respectively of the element $x \in E$ to the set $A$, which is a subset of $E$, and for every $x \in E, 0 \leq \mu_{A}(x)+\gamma_{A}(x) \leq 1$. 
The amount $\Pi_{A}(x)=1-\left(\mu_{A}(x)+\gamma_{A}(x)\right)$ is called the hesitation part, which may cater to either membership value or non-membership value or both.

\section{Definition}

If $\mathrm{A}$ and $\mathrm{B}$ are two IFS of the set $\mathrm{E}$, then $\mathrm{A} \subset \mathrm{B}$ if and only if $\forall \mathrm{x} \in \mathrm{E},\left[\mu_{A}(x) \leq \mu_{B}(x)\right.$ and $\gamma_{A}(x) \geq$ $\left.\gamma_{B}(x)\right] \mathrm{A} \subset \mathrm{B}$ iff $\mathrm{B} \supset \mathrm{A}, \mathrm{A}=\mathrm{B}$ iff $\forall \mathrm{x} \in \mathrm{E}$,

$\left[\mu_{A}(x) \leq \mu_{B}(x)\right.$ and $\left.\gamma_{A}(x) \geq \gamma_{B}(x)\right]$,

$\bar{A}=\left\{\left\langle x, \gamma_{A}(x), \mu_{A}(x)\right\rangle / \mathrm{x} \in \mathrm{E}\right\}$,

$\mathrm{A} \cap \mathrm{B}=\left\{\left\langle x, \min \left(\mu_{A}(x), \mu_{B}(x)\right), \max \left(\mathrm{F}_{A}(x), \gamma_{B}(x)\right)\right\rangle / \mathrm{x} \in \mathrm{E}\right\}$

$\mathrm{AUB}=\left\{\left\langle x, \max \left(\mu_{A}(x), \mu_{B}(x)\right), \min \left(\gamma_{A}(x), \gamma_{B}(x)\right)\right\rangle / \mathrm{x} \in \mathrm{E}\right\}$.

Obiviously every fuzzy set has the form $\left\{\left\langle x, \mu_{A}(x), \mu_{A^{c}}(x)\right\rangle / \mathrm{x} \in \mathrm{E}\right\}$.

\section{Definition}

Let $\mathrm{Q}(\mathrm{X} \rightarrow \mathrm{Y})$ and $\mathrm{R}(\mathrm{Y} \rightarrow \mathrm{Z})$ be two IFR. The max-min-max composition RoQ is the Intuitionistic fuzzy relations from $X$ to $Z$, defined by the membership function,

$\mu_{\mathrm{RoQ}}(\mathrm{x}, \mathrm{z})=\mathrm{V}\left(\mu_{Q}(x, y) \wedge \mu_{R}(y, z)\right)$ and the non-membership function

$\gamma_{\mathrm{RoQ}}(\mathrm{x}, \mathrm{z})=\Lambda\left(\gamma_{Q}(x, y) \backslash \gamma_{R}(y, z)\right) \forall \mathrm{x} \in(\mathrm{x}, \mathrm{z}) \in \mathrm{X} \times \mathrm{Z}$ and $\forall \mathrm{y} \in \mathrm{Y}$.

Analysis of Students Problems that affects their Studies

In this section we present an application of intuitionistic fuzzy set theory in Sanchez's approach [13, 14] for Analysis of Students Problems that Affects their Studies.

In a given pathology, suppose $\mathrm{M}$ is a set of Marks, $\mathrm{P}$ a set of Problems, and $\mathrm{S}$ a set of Students. we define an intuitionistic fuzzy relation R from the set of Marks M to the set of Problems P(i.e., on M x P) which reveals the degree of

association and the degree of non-association between Marks and Problems.

Now let us discuss intuitionistic fuzzy medical analysis. The methodology involves

mainly the following three jobs:

1. Determination of Marks.

2. Formulation of Problems that affects their studies based on intuitionistic fuzzy relations.

3. Determination of Problems on the basis of composition of intuitionistic

fuzzy relations.

An intuitionistic fizzy relation $\mathrm{Q}$ is given from the set of Students $\mathrm{S}$ to the set of Marks $\mathrm{M}$ and another intuitionistic fuzzy relation $\mathrm{R}$ is given from a set of Marks S to the set of Problems P.

The composition $\mathrm{T}$ of intuitionistic fuzzy relation $\mathrm{R}$ and $\mathrm{Q}$.

\section{Algorithm}

(1) Compute $\mathrm{T}=\mathrm{R}$ o Q

(2) Compute $\mathrm{S}$, \{Where $\mathrm{S}=\left\{\mu_{A}(s i, s), \mu_{A^{c}}(s i, s)\right\}$ non-members in $\mathrm{T}$ i.e., $\left.\mu_{A^{c}}(s i, s)=1-\gamma_{A}(s i, s)\right\}$ converting as members in $\mathrm{S}$.

(3) Find $\operatorname{Min}\left\{\mu_{A}(s i, s), \mu_{A^{c}}(s i, s)\right\}$

(4) Find $\operatorname{Max}\left\{\operatorname{Min}\left\{\mu_{A}(s i, s), \mu_{A^{c}}(s i, s)\right\}\right\}$ then

We conclude that the students $s i$ is facing different problems that affects their studies pj (i.e., $\mathrm{j}=1$, $2,3,4,5)$.

\section{Case Study}

We have taken Survey from the Students in which they are facing many problems that affects their studies in which we have choosen the most common problems. Among the students we have consider only four students for example. In the discrimination analysis, the Marks are ranked according to the grade of discrimination of each problem and is represented in the form of a matrix called a frequency distribution matrix $\mathrm{F}=(\mathrm{fij})$ where fij is the ratio of the students with marks ' $\mathrm{m}_{\mathrm{i}}$ ' and problem ' $\mathrm{p}_{\mathrm{j}}$ ' to the total number of students with problems ' $p_{j}$ '.

Let us consider four Students Raj, Kumar, Praveen and Vicky are denoted by the set $S=\{$ Raj, Kumar, Praveen, Vicky\}

and the set of Marks $M=\left\{M_{1}, M_{2}, M_{3}, M_{4}, M_{5}\right\}$. 
Let the set of Problems be

$\mathrm{P}=\{$ Drowziness, Adolocent Problem, Family Problem,Financial Problem $\}$.

Table 1 represents the Determination of Marks by using intuitionistic fuzzy relation $Q(S \rightarrow M)$ in which the entries as per the survey are in the form of IFS $\left(\mu_{A}, \gamma_{A}\right)$

Table $1 \quad Q(S \rightarrow M)$

\begin{tabular}{|l|l|l|l|l|l|}
\hline $\mathbf{Q}$ & $\mathbf{M}_{\mathbf{1}}$ & $\mathbf{M}_{\mathbf{2}}$ & $\mathbf{M}_{\mathbf{3}}$ & $\mathbf{M}_{\mathbf{4}}$ & $\mathbf{M}_{\mathbf{5}}$ \\
\hline Raj & $(0.6,0.2)$ & $(0.5,0.1)$ & $(0.3,0.9)$ & $(0.5,0.2)$ & $(0.3,0.5)$ \\
\hline Kumar & $(0,0.7)$ & $(0.5,0.5)$ & $(0.7,0.1)$ & $(0.2,0.6)$ & $(0.1,0.6)$ \\
\hline Praveen & $(0.5,0.1)$ & $(0.7,0.1)$ & $(0,0.7)$ & $(0.3,0.8)$ & $(0,0.4)$ \\
\hline Vicky & $(0.8,0.1)$ & $(0.5,0.4)$ & $(0.3,0.2)$ & $(0.8,0.2)$ & $(0.4,0.3)$ \\
\hline
\end{tabular}

The intuitionistic fuzzy relation $\mathbf{R}(\mathbf{M} \rightarrow \mathbf{P})$ is given as in Table 2.

Table $2 \quad \mathbf{R}(\mathbf{M} \rightarrow \mathbf{P})$

\begin{tabular}{|l|l|l|l|l|l|}
\hline $\mathbf{R}$ & $\begin{array}{l}\text { Drowzine } \\
\text { SS }\end{array}$ & $\begin{array}{l}\text { Adolocent } \\
\text { Problem }\end{array}$ & $\begin{array}{l}\text { Family } \\
\text { Problem }\end{array}$ & $\begin{array}{l}\text { Financial } \\
\text { Problem }\end{array}$ & $\begin{array}{l}\text { Memory } \\
\text { Loss }\end{array}$ \\
\hline $\mathbf{M}_{\mathbf{1}}$ & $(0.4,0.3)$ & $(0.5,0.6)$ & $(0.2,0.2)$ & $(0.1,0.6)$ & $(0.2,0.7)$ \\
\hline $\mathbf{M}_{\mathbf{2}}$ & $(0.2,0.4)$ & $(0.3,0.5)$ & $(0.5,0.1)$ & $(0.1,0.3)$ & $(0,0.6)$ \\
\hline $\mathbf{M}_{\mathbf{3}}$ & $(0.1,0.3)$ & $(0,0.7)$ & $(0.2,0.7)$ & $(0.8,0)$ & $(0.1,0.5)$ \\
\hline $\mathbf{M}_{\mathbf{4}}$ & $(0.3,0.4)$ & $(0.6,0)$ & $(0.1,0.5)$ & $(0.1,0.6)$ & $(0.1,0.3)$ \\
\hline $\mathbf{M}_{\mathbf{5}}$ & $(0.3,0.2)$ & $(0.1,0.8)$ & $(0.2,0.8)$ & $(0.2,0.7)$ & $(0.7,0.2)$ \\
\hline
\end{tabular}

The Max-Min Composition $\mathrm{T}$ of RoQ in Table 3.

Table $3 \quad \mathrm{~T}(\mathrm{~S} \rightarrow \mathrm{P})$

\begin{tabular}{|l|l|l|l|l|l|}
\hline T & $\begin{array}{l}\text { Drowzi } \\
\text { ness }\end{array}$ & $\begin{array}{l}\text { Adolocen } \\
\text { t Problem }\end{array}$ & $\begin{array}{l}\text { Family } \\
\text { Problem }\end{array}$ & $\begin{array}{l}\text { Financia } \\
\text { l } \\
\text { Problem }\end{array}$ & $\begin{array}{l}\text { Memory } \\
\text { Loss }\end{array}$ \\
\hline Raj & $(0.4,0.1)$ & $(0.5,0.2)$ & $(0.5,0.1)$ & $(0.3,0.3)$ & $(0.3,0.3)$ \\
\hline Kumar & $(0.2,0.3)$ & $(0.3,0.5)$ & $(0.5,0.5)$ & $(0.7,0.1)$ & $(0.1,0.5)$ \\
\hline Praveen & $(0.4,0.3)$ & $(0.5,0.5)$ & $(0.5,0.1)$ & $(0.1,0.3)$ & $(0.2,0.4)$ \\
\hline Vicky & $(0.4,0.3)$ & $(0.6,0.2)$ & $(0.5,0.2)$ & $(0.3,0.2)$ & $(0.4,0.3)$ \\
\hline
\end{tabular}


Here Table 4 is represented by $V=\left(\mu_{A}, \mu_{A^{c}}\right)$ where $\mu_{A^{c}}=1-\gamma_{A}$.

Table $4 \quad \mathrm{~V}(\mathrm{~S} \rightarrow \mathrm{P})$

\begin{tabular}{|l|l|l|l|l|l|}
\hline V & $\begin{array}{l}\text { Drowzi } \\
\text { ness }\end{array}$ & $\begin{array}{l}\text { Adoloce } \\
\text { nt } \\
\text { Problem }\end{array}$ & $\begin{array}{l}\text { Family } \\
\text { Problem }\end{array}$ & $\begin{array}{l}\text { Financi } \\
\text { al } \\
\text { Proble } \\
\text { m }\end{array}$ & $\begin{array}{l}\text { Memory } \\
\text { Loss }\end{array}$ \\
\hline Raj & $(0.4,0.9)$ & $(0.5,0.8)$ & $(0.5,0.9)$ & $(0.3,0.7)$ & $(0.3,0.7)$ \\
\hline Kumar & $(0.2,0.7)$ & $(0.3,0.5)$ & $(0.5,0.5)$ & $(0.7,0.9)$ & $(0.1,0.5)$ \\
\hline Praveen & $(0.4,0.7)$ & $(0.5,0.5)$ & $(0.5,0.9)$ & $(0.1,0.7)$ & $(0.2,0.6)$ \\
\hline Vicky & $(0.4,0.7)$ & $(0.6,0.8)$ & $(0.5,0.8)$ & $(0.3,0.8)$ & $(0.4,0.7)$ \\
\hline
\end{tabular}

Table 5 represents $\operatorname{Min}\left\{\mu_{A}(w i, h), \mu_{A^{c}}(w i, h)\right\}$

Table 5 F $(\mathbf{S} \rightarrow \mathrm{P})$

\begin{tabular}{|l|l|l|l|l|l|}
\hline F & $\begin{array}{l}\text { Dro } \\
\text { wzin } \\
\text { ess }\end{array}$ & $\begin{array}{l}\text { Adolocen } \\
\text { t Problem }\end{array}$ & $\begin{array}{l}\text { Family } \\
\text { Problem }\end{array}$ & $\begin{array}{l}\text { Financial } \\
\text { Problem }\end{array}$ & $\begin{array}{l}\text { Memory } \\
\text { Loss }\end{array}$ \\
\hline Raj & 0.4 & $\mathbf{0 . 5}$ & $\mathbf{0 . 5}$ & 0.3 & 0.3 \\
\hline Kumar & 0.2 & 0.3 & 0.5 & $\mathbf{0 . 7}$ & 0.1 \\
\hline Praveen & 0.4 & $\mathbf{0 . 5}$ & $\mathbf{0 . 5}$ & 0.1 & 0.2 \\
\hline Vicky & 0.4 & $\mathbf{0 . 6}$ & 0.5 & 0.3 & 0.4 \\
\hline
\end{tabular}

IV. Conclusion

Overall the $\operatorname{Max}\left\{\operatorname{Min}\left\{\mu_{A}(w i, h), \mu_{A^{c}}(w i, h)\right\}\right\}$ gives the final result of the Students problems that affects their studies is from Table 5, we see that the max value of Raj is 0.5 . This concludes that Raj's Studies affected by Adolocent \& Family Problem. The max value of Kumar is 0.7 and therefore Kumar's Studies affected by Financial Problem whereas the max value of Praveen is 0.5 and therefore Praveen's Studies affected by Adolocent \& Family Problems. The max value of Vicky is $0.6 \&$ his studies affected by Adolocent Problem. This is represented by the Chart diagram as follows:

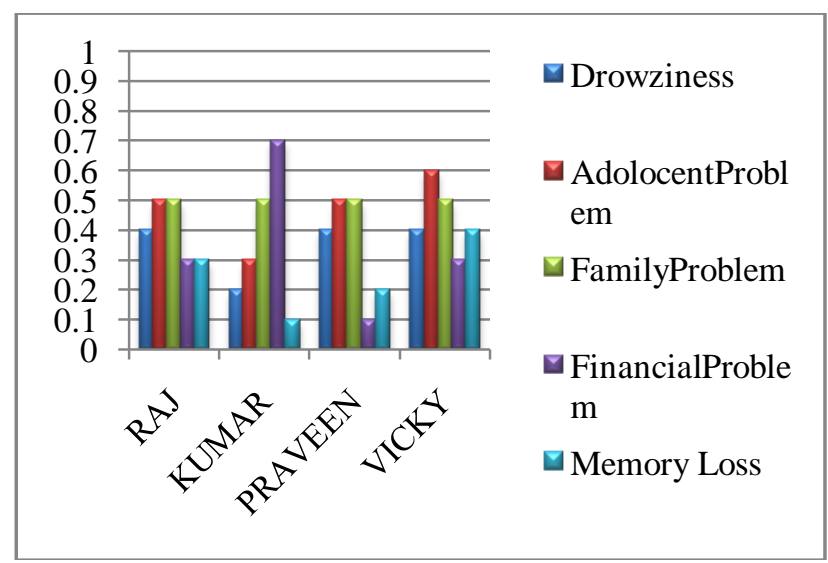




\section{Acknowledgments}

I Thank IJATER Journal for the support to develop this document and I Thank my husband Mr.K..Raman for his full motivation and support.Also I Thank my inlaws and my parents for their support.

\section{References}

[1] K. Atanassov, Intuitionistic fuzzy sets, Fuzzy Sets and Systems, 20 (1986), 87-96

[2] K. Atanassov, New operations defined over intuitionistic fuzzy sets, Fuzzy Sets and Systems, 61 (1994), 137-142.

[3] K. Atanassov, More on intuitionistic fuzzy sets, Fuzzy Sets and Systems, 33(1989), 37-46.

[4] K. Atanassov, Remarks on the intuitionistic fuzzy sets - III, Fuzzy Sets and Systems, 75 (1995), 401-402.

[5] K. Atanassov, G.Gargov, Intuitionistic fuzzylogic, C.R. Acad. Bulgare Sc., 43 (3) (1990), 9-12.

[6] K. Atanasoov, C. Georgeiv, Intuitionistic fuzzy prolog, Fuzzy Sets and Systems,53 (1993), 121-128.

[7] R. Biswas, Intuitionistic fuzzy relations, Bull. Sous.Ens. Flous. Appl.(BUSEFAL), 70 (1997), 22-29.

[8] R. Biswas, On fuzzy sets and intuitionistic fuzzy sets,NIFS, 3 (1997), 3-11.

[9] H. Bustince, P. Burillo, Vague sets are intuitionistic fuzzy sets, Fuzzy Sets and Systems, 79 (1996), 403 - 405

[10] D. Doubois, H. Prade, Fuzzy Sets and Systems; Theory and Application,Academic Press, New York, 1980.

[11] W.L. Gau, D.J. Buehrer, Vague sets, IEEE Trans.Systems Man Cybernet, 23 (2), (1993), 610-614.

[12] A. Kaufmann, An Introduction to the Theory ofFuzzy Subsets, vol. 1,Academic Press, New York,

[13] E. Sanchez, Solutions in composite fuzzy relation equation. Application to Medical diagnosis in Brouwerian Logic, in: M.M. Gupta, G.N. Saridis, B.R. Gaines (Eds.), Fuzzy Automata and Decision Process, Elsevier, North-Holland,1977.

[14] E. Sanchez, Resolution of composition fuzzy relation equations, InformControl, 30 (1976), 38 - 48

[15] Supriya Kumar De, Ranjit Biswas, Akhil Ranjan Roy, An application of intuitionistic fuzzy sets in medical diagnosis, Fuzzy Sets and Systems, 117(2001), 209-213.

[16] A. Edward Samuel and M. Balamurugan, FuzzyMax-Min Composition Tecnique in Medical Diagnosis,Applied Mathematical Sciences,vol.6,(2012),no.35,1741-1746.

[17] http://sssihl.academia.edu/SaiHareeshAnamandra/papers/1330024/similarit _between_max_min_and _R_V_technique_with_reference_to_two_diseases_diarrhea_and_diabetes

[18] http://www.intelligent-systems.info/classes/ee509/6.pdfBiographies

\section{FIRST A. M.GEETHALAKSHMI}

received the M.phil degree in Mathematics from Alagappa University, Karaikudi,TamilNadu, in 2006, Currently, She is an assistant Professor of Mathematics at KCG College of Techniology. Her teaching and research areas include fuzzy theory and fuzzy matrices, fuzzy control system. She has authored journals like : Result analysis of Students marks using fuzzy matrices, An analysis of IT Workers affected by health problems due to stress using fuzzy matrix solutions, Estimation of age group for the IT worker affected by diseases due to work pressure. Author may be reached at

SECOND B. A.RAJKUMAR, currently,He is an assistant professor in Hindustan University, Second Author may be reached at THIRD C. N.JOSE PARVIN PRAVEENA,

Currently, She is an assistant Professor of Mathematics at KCG College of Techniology, Third Author may be reached at 